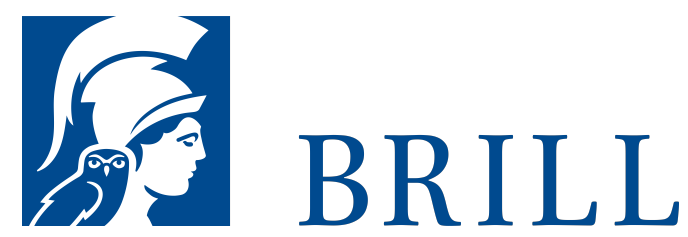

\title{
Textes grecs, démotiques et bilingues
}

Édités par divers auteurs

Authors: P.W. Pestman and Boswinkel

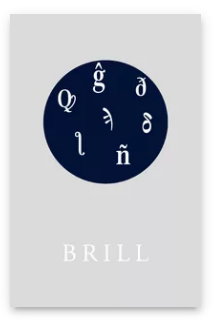

Pages: $\mathrm{x}, 286 \mathrm{pp}$. fold. table, 28 plates

Language:

French

Subjects:

General,

Classical Studies

Publisher: Brill

Series:

Papyrologica

Lugduno-

Batava, Volume:

19

E-Book (PDF)

Released online:

O2 Mar $202 \mathrm{O}$

ISBN: 978-90-

04-42771-6

List price

USD \$224.00

Paperback

Publication date:

o1 Dec 1978

ISBN: 978-9O-

04-05772-2 
For more information see brill.com

Order information: Order online at brill.com +44330 333 0049 | customerservices@brill.com Submission information: brill.com/authors

Titles published by Brill | Fink, Brill | mentis or Brill | Schöningh: +49(o)715413279216| brill@brocom.de 